\title{
継続架工義霜に機能コアーを応用した症例
}

腰 原 好* 太田是男 潤田和好

\section{Clinical Reports of a Functional Core practiced to the Crown and Bridge Works}

Yoshimi Koshihara, Yoshio Ohta, and Kazuyoshi Uruta

\section{緒言}

菊科補経や局部義歯の場合に，多くの症例が上下顎㖫 合する残存歯列を有するので補綴する人工歯の咬合面 は，残存歯列の咬合面や顆路によって規制される頻運動 に調和したものでなけ机ばならない，特に陶材の利用度 の高い今日，その応用にあたり人工菌沉強度を得る目的

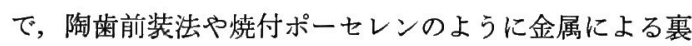
装を抗こなら方法が多くこころみられている。その場合 に金属の厚みが重要な要素となり，もしこれを誤ると陶 增の破損や支持組織の破壞をきたすことになる(図1). これ等不快事項を防止し，しかも義菌の機能を满足させ るには, どうしても義齿調製過程において頻運動,特に 唂合滑走運動を記録し，それをガイドにする必要があ る. その手段として従来より種々な方法が用いられて

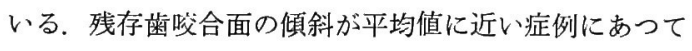

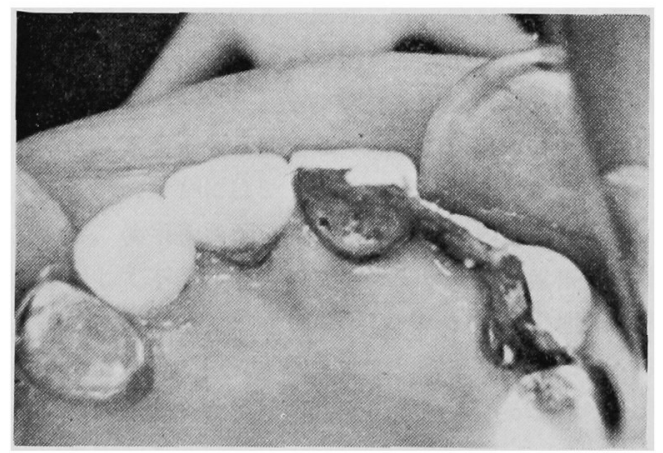

図 1 前装陶歯の破損

は, 簡単な平均值咬合器によつてもほぼ近似的な運動路 が得られるが，その適応性を判断するのが困難なのが現 状である. 大部分の症例においては, 咬合面が種タの傾

* Dept. of Prosthetic Dentistry, Tokyo Dental College (Director: Prof. M. Haga) 東京歯科大学補緅学教室（指導：羽賀通夫教授）
斜を有していることが多くまた運動も多様であり，その 運動路を追跡するには, かなり精巧な調節性の高い咬合 器と技術によらなければならない.あるいはこの目的の ために作られた Hanau 社の Twin stage occludor と か, Jelenko 社の Verticulator を使用するか,これに 類する構造をもつた咬合器または自由運動咬合器を使用 しなければならない.

このような調節性または特殊な咬合器を用いずして, 比較的簡単に機能時の滑走運動を記録し再現する方法を 試みて好結果を得た.この術式を上顎前歯架工義歯と上 顎臼歯に陶歯前装の鋳造冠に応用したので報告する.

\section{咬 合 器 付 着}

通法にしたがつてラバーで精密印象を行ない, 超硬石

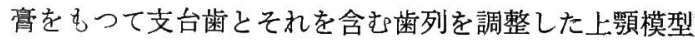
と, 解剖的な下影歯列模型とを中心咬合位が正確に得ら れるような咬合器に中心咬合位で付着する.

\section{滑走運動路の記録}

上顎臼歯補経の症例においては，バイト・ワックスを 2 枚にかさね側方滑運動距離である約 $3 \mathrm{~mm}$ の厚さにし 支台歯とその両隣在歯を含む咬合面および煩面を被覆し てこれを圧接し適合をはかる，咬合面のワックスを軟化 し, 静かに中心位に咬合させた後, 下頡を側方に滑走さ せる. この時バイト・ワックスの余剩部が，煩側に圧流 されるため指頭で煩側よりワックスを固定し歯列との位 置関係を確保する。この操作を数回くりかえし中心咬合 位および側方の機能咬合位をバイト・ワックスに印記す 万(図 2 ).

上顎前歯の場合は運動路をソフト・ワックスで印記す ると同時にソフト・ワックスの変形を防ぐ目的と人工歯 唇面の位置や正中線ならびに切端の位置を印記するため 唇側にパラフィン・ワックスで堤をつくる（図 3 ). 

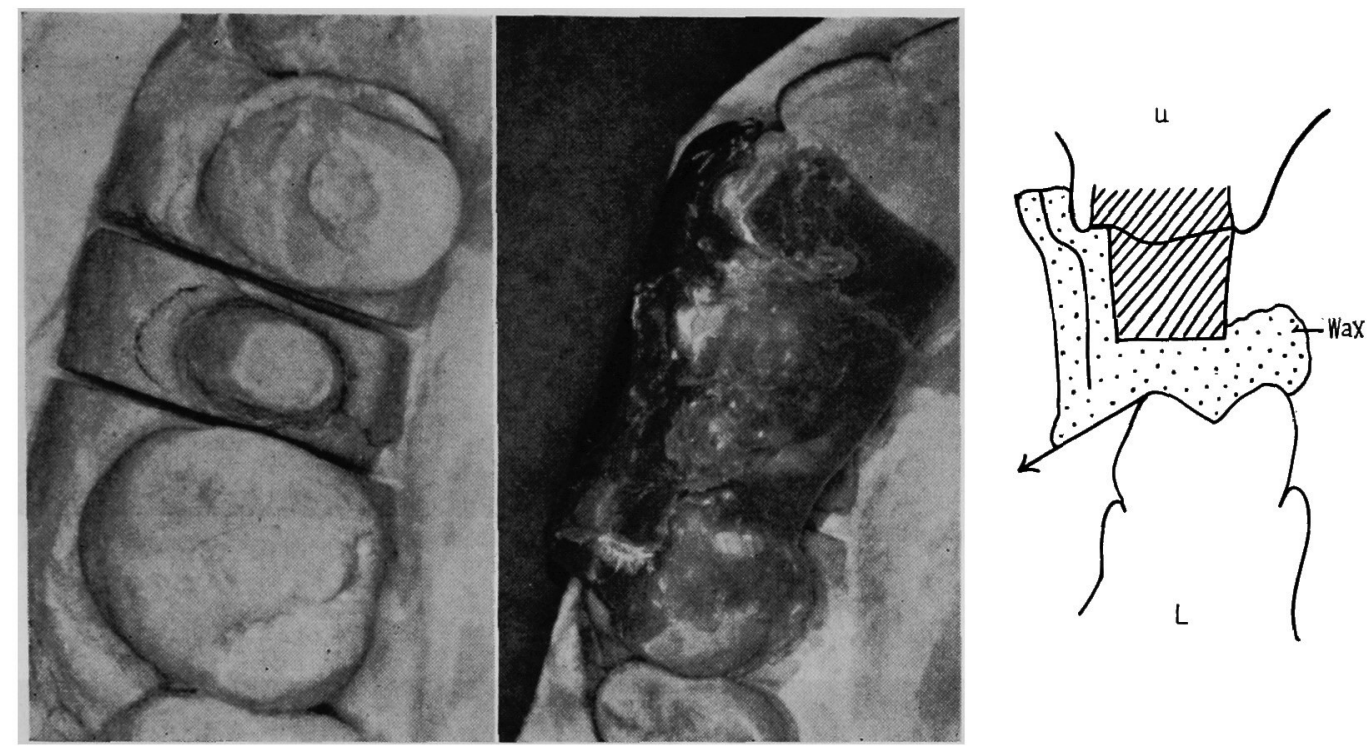

滑走運動路の記録

図 2 上額日歯補棳

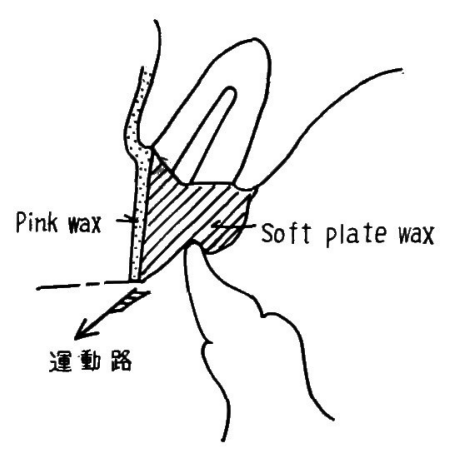

図 3 上䫑前莼運動路の記録
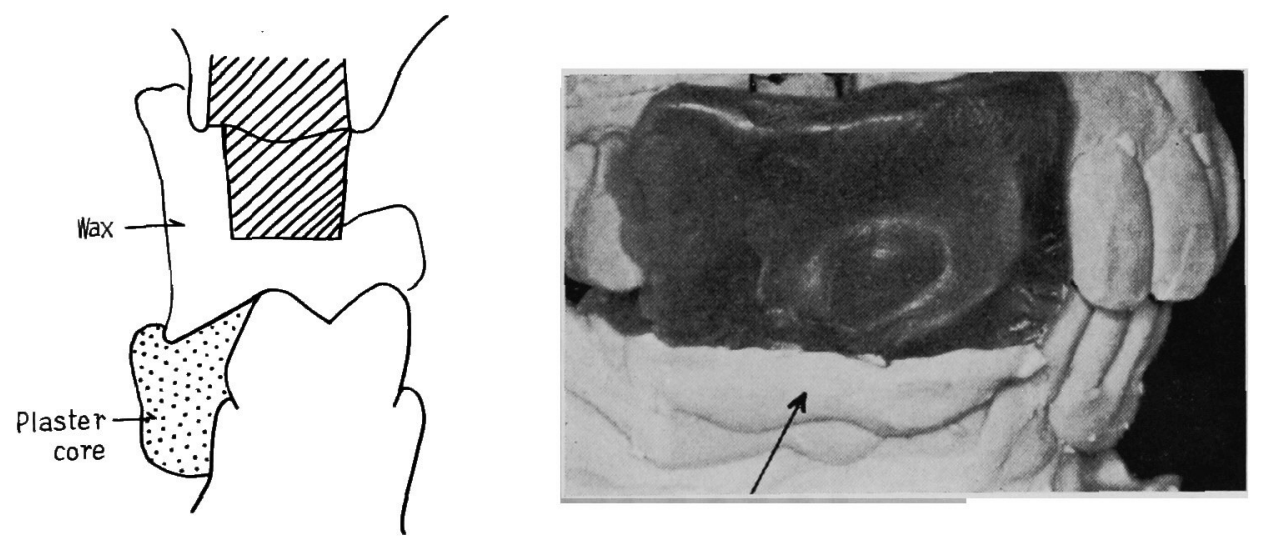

図 4-1 白歯部の機能コアー

$$
101-201
$$




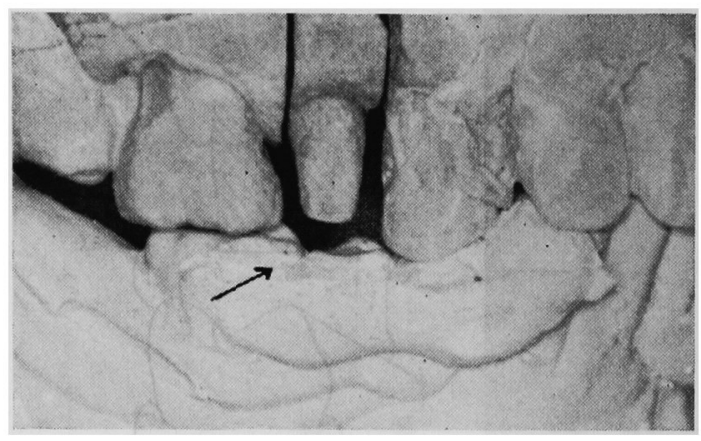

頗 面

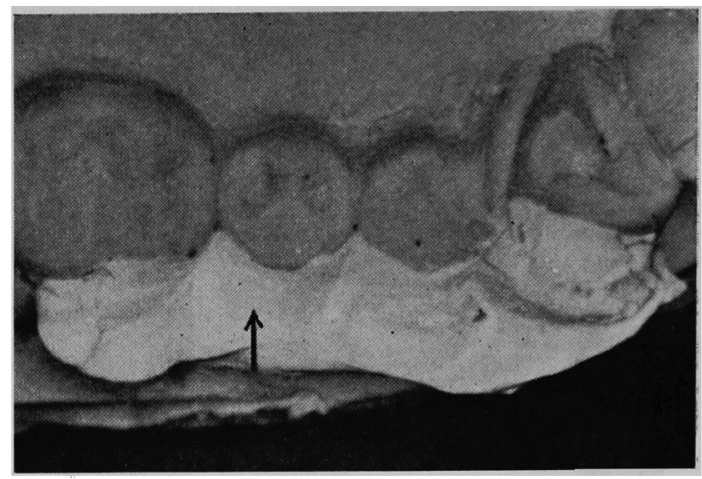

咬合面

図 4-2 白歯部の機能コアー
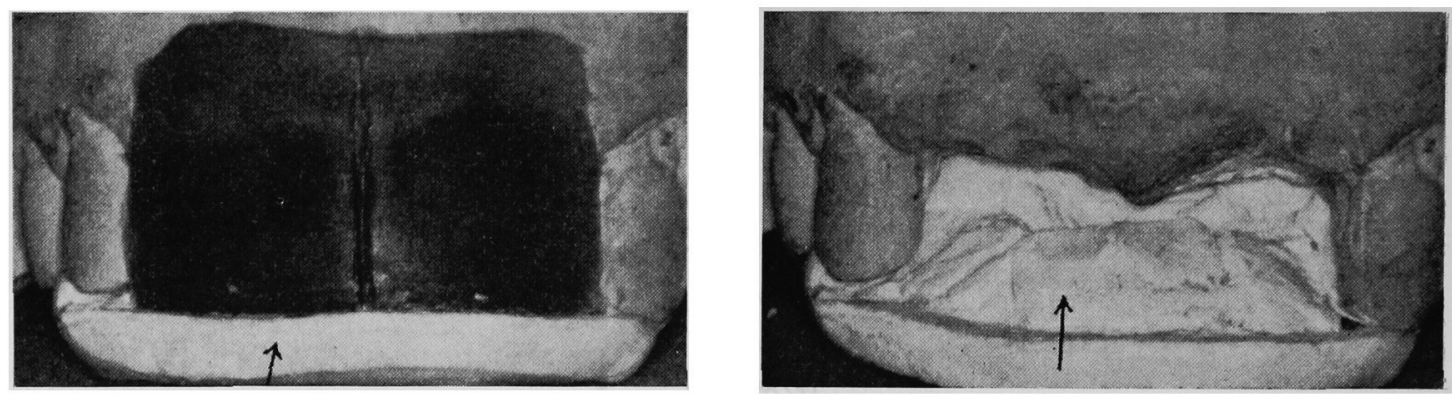

図 4-3 前歯部の機能コアー

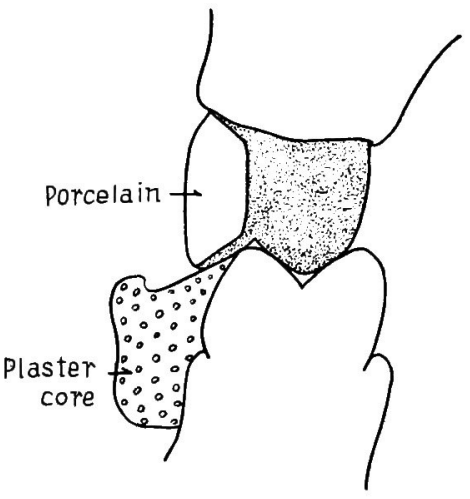

白歯

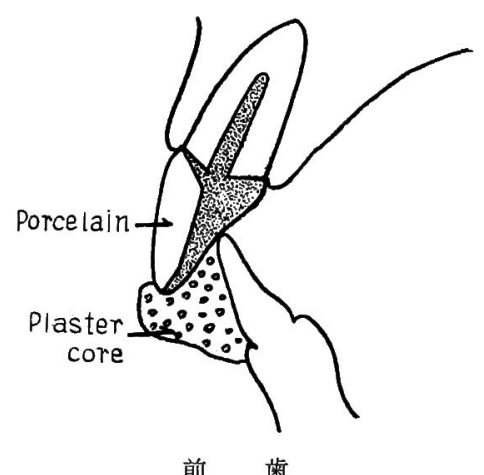

前歯

图 5-1 コアーと人工画 


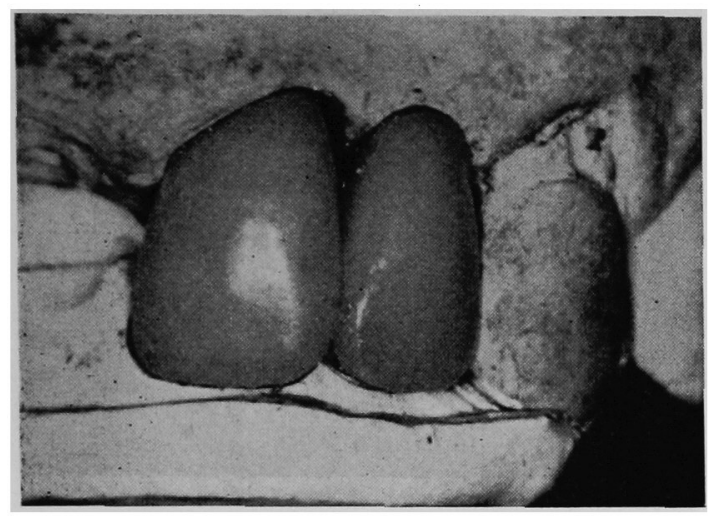

唇面

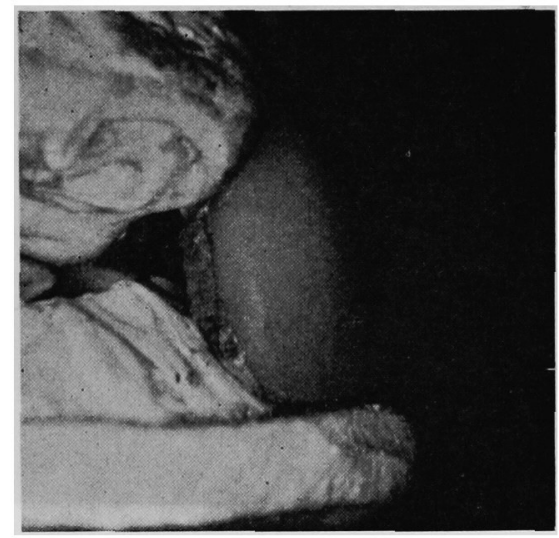

側 面

図 5-2 コアーへ人工歯を適合したところ
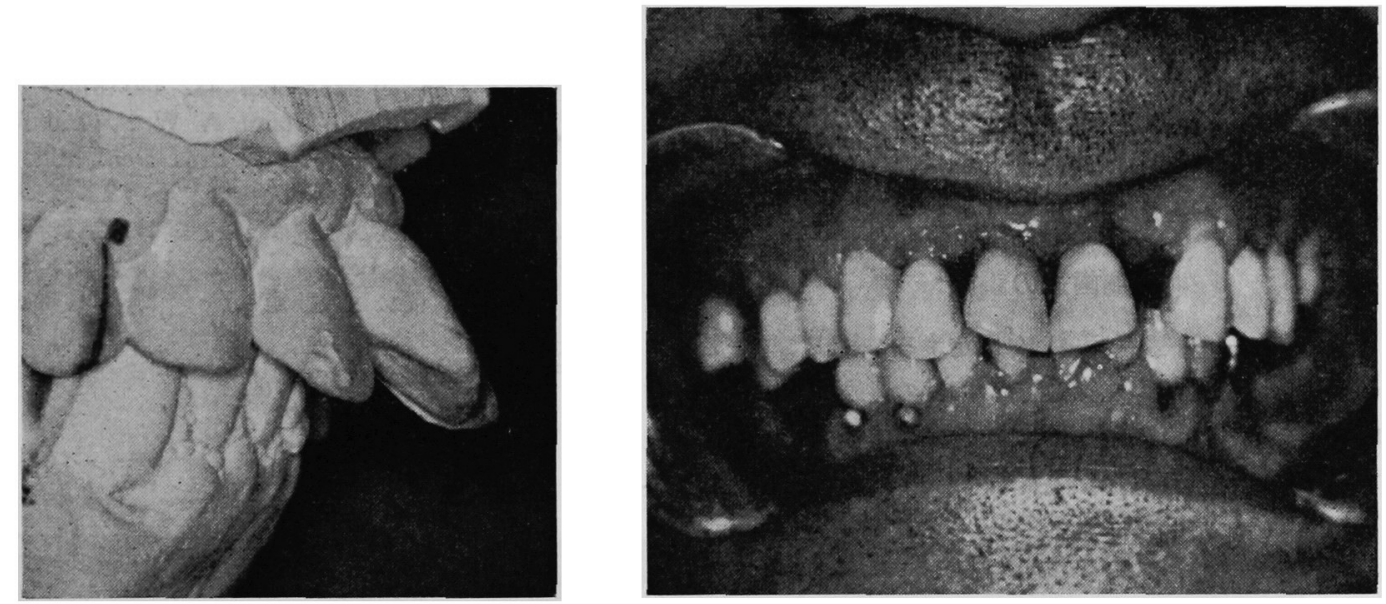

図 6-1 義歯装着 前
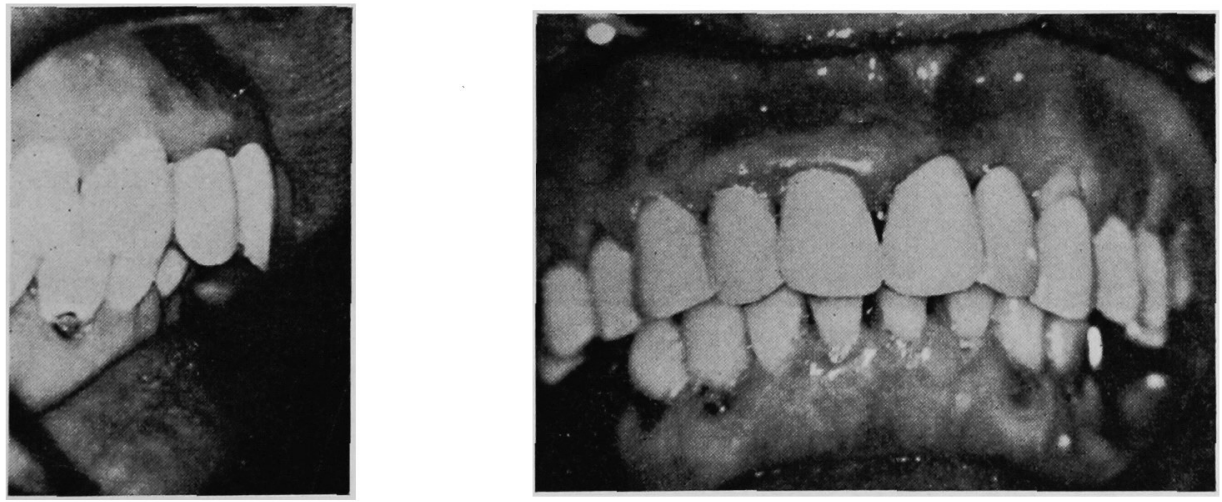

図 6-2 義歯装着後 

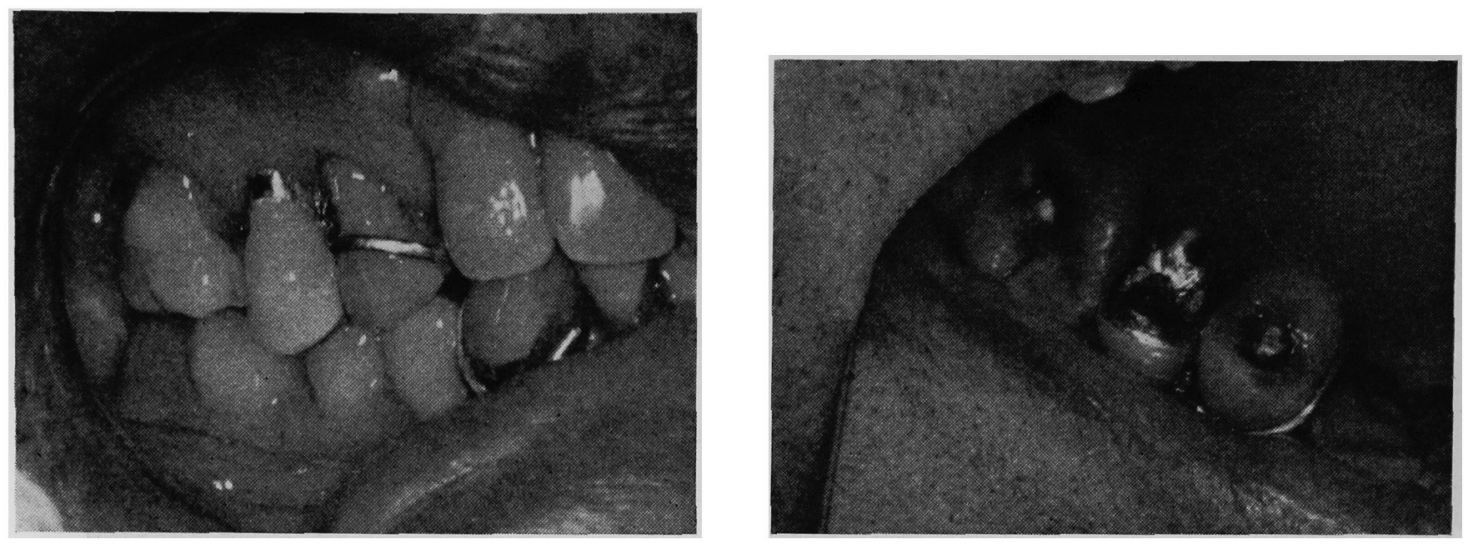

図 6-3 白歯の適合

\section{機能コアーの調製}

運動路を記録したパイト・ワックスを上說歯列模型に 適合させ上下䫓歯列模型を中心位に咬合させる. バイ

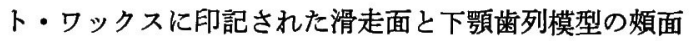
（上䇗前歯の症例では唇面）との間に楔状の凹窩ができ る.この部に石膏を注ぎ機能コアーをつくる(図4).

\section{陶雪冠の調製}

機能コアーを下䫟歯列模型に固定することにより必要 とする裹装金属の厚みを考虑した陶歯の形態を容易に形 成することができる（図 5). 以下通法にしたがって義 歯を完成する（図6）.

\section{参考文献}

1) Meyer, F. S. : The Generated Path Technic in Reconstruction Dentistry, Part 1 and 2; J. Pros. Den., 9 : 354-366, 432-440 (May), 1959.

2) Panky, L. D. and Mann, A. W. : Oral Rehabilitation, Part 1, 2; J. Pros. Den., 10 : 135162 (Jan). 1960.

3）関根弘：間接法の問題点（その 1), 歯科時報, 19 , 7, 20(7月), 1965 .

4）関根弘：間接法の問題点(その 2), 歯科時報, 19 , 9, 36(9 月), 1965.

5) 山田早苗訳：クラウン・ブリッジの製作法, p. 112-122, 東京, 1966. 